\title{
Influence of Integrated Nitrogen Nourishment on Seed yield and Energetics of Safflower in Hybrid rice- Safflower Cropping System
}

\author{
P. K. Mishra* \\ JNKVV, College of Agriculture- Ganjbasoda (Vidisha), India \\ *Corresponding author
}

A B S T R A C T

\section{Keywords \\ Hybrid rice, \\ Safflower integrated nitrogen \\ Nourishment, Energetics \\ Article Info \\ Accepted: \\ 22 December 2019 \\ Available Online: \\ 20 January 2020}

\section{Introduction}

Safflower (Carthamus tinctorius L.) is a rabi oilseed crop traditionally grown on black clay soils on residual moisture. It is grown in different cropping regions in the world between $50^{\circ}$ and $23^{\circ}$ latitudes in Northern and southern hemispheres. Safflower is an important oilseed crop cultivated in India for cooking oil and dye from the flowers. Meal after oil extraction is used as a protein supplement for livestock, which contains about 24 per cent protein and a lot of fibre (Oelke et al.,1992). Safflower seed contains 28-34 per cent of oil which is flavourless, colourless and nutritionally similar to sunflower oil (Reddy et al., 1994), having enough amount of linoleic acid (78\%) useful for reducing blood cholesterol content.

Chemical fertilizers will continue to be the main components for meeting the increased crop nutrient needs of the country. But due to energy crisis, their use has become costlier input, which constitutes about 30-40 per cent of the farmer's budget for cereal production. Application of organic materials to the soil will improve the hydro-physical environment and fertility level (Wani et al., 1994). However, due to paucity of organic sources to meet the total nutrient requirement of the crops, their integrated use with inorganic sources is desirable. Consumption of energy has been increasing in steady state for 
improving the productivity in Indian agriculture. But energy use efficiency is declining consistently. Climate, soil and management factors greatly influence the crop productivity. Thus, both non renewable and renewable and natural energy sources contribute a lot in increasing productivity of crops. Non renewable sources of energy, which are exhaustible nature, dominate the major share in total energy inputs consumed in farming systems. Information on energetic of safflower is lacking. Thus the present investigation was undertaken to study the effect of integrated nitrogen nourishment on energetic of safflower in hybrid ricesafflower cropping system.

\section{Materials and Methods}

Field experiment was carried out at Instructional Farm, Indira Gandhi Agricultural University, Raipur during kharif and rabi season of 2001-02 and 2002-03 in hybrid rice-safflower cropping system. The soil was sandy loam in texture and neutral in reaction. The treatments of nitrogen nourishment i.e. $\mathrm{N}_{0^{-}}$Control, $\mathrm{N}_{1}-100 \%$ rec. (recommended) $\mathrm{N}, \mathrm{N}_{2}-75 \%$ rec. $\mathrm{N}, \mathrm{N}_{3}-75 \%$ rec. $\mathrm{N}+25 \% \mathrm{~N}(\mathrm{FYM}), \mathrm{N}_{4}-75 \%$ rec. $\mathrm{N}+$ $25 \% \mathrm{~N}$ (poultry manure), $\mathrm{N}_{5^{-}} 75 \%$ rec. $\mathrm{N}+$ $25 \% \mathrm{~N}$ (wheat straw), $\mathrm{N}_{6-} 75 \%$ rec. $\mathrm{N}$ blended with cow dung urine (CDU) mixture, $\mathrm{N}_{7-} 75 \%$ rec. $\mathrm{N}$ blended with cow dung, $\mathrm{N}_{8^{-}}$ $75 \%$ rec. $\mathrm{N}+\mathrm{BGA} 10 \mathrm{~kg} \mathrm{ha}^{-1}$ and growth regulators i.e. $\mathrm{T}_{1^{-}}$Control, $\mathrm{T}_{2^{-}}$cyclocel @ 1000 ppm, T $3^{-}$brassinolide @ 200 ppm and $\mathrm{T}_{4^{-}}$tricontanol @ 5 ppm were applied in hybrid rice. With allocation of nitrogen nourishment and growth regulators were in main plot and sub plot respectively. In safflower, the nitrogen nourishment to hybrid rice treatments were allocated in main plots and studied as residual treatments. Similarly, $\mathrm{T}_{1^{-}}$no nitrogen, $\mathrm{T}_{2^{-}} 50 \%$ rec. $\mathrm{N}+$ Azotobacter, $\mathrm{T}_{3}-50 \%$ rec. $\mathrm{N}+$ Azotobacter + Azospirillum, $\mathrm{T}_{4^{-}} 100 \%$ rec. $\mathrm{N}$ were applied to safflower and their effect was studied as direct effect. Split plot design was used with three replications. Recommended dose of $\mathrm{N}$ for hybrid rice was $150 \mathrm{~kg} \mathrm{~N} \mathrm{ha}^{-1}$ and for safflower $60 \mathrm{~kg} \mathrm{~N}^{-1}$ applied in two splits i.e. $50 \%$ basal and $50 \%$ at $\mathrm{I}^{\text {st }}$ irrigation. The safflower variety A-1 was taken as the test variety. Total energy consumed under each treatment was computed. For estimation of energy inputs and outputs the equivalent coefficient were used as suggested by Mittal and Dhawan (1988). Energy productivity was calculated by using the formula given by Paneswar and Bhatnagar (1994) and Energy intensiveness was calculated by using the formula given by Burnett (1982).

Energy efficiency $=$

$$
\frac{\text { Total produce }(\mathrm{q})}{\text { Energy input }\left(\mathrm{MJ} \times 10^{-3}\right)}
$$

Energy productivity $=$

$$
\frac{\text { Mean grain yield }(\mathrm{g})}{\text { Total energy input }(\mathrm{MJ})}
$$

Energy intensiveness $=$

$$
\frac{\text { Total energy output (MJ) }}{\text { Total cost incurred (Rs) }}
$$

\section{Results and Discussion}

Seed yield of safflower was higher under the residual of 75 rec. $\mathrm{N}$ blended with $\mathrm{CDU}$ during both the years (Table 1). All the treatments having different combination of organic and inorganic sources of nitrogen were at par except $75 \%$ re. $\mathrm{N}+25 \% \mathrm{~N}(\mathrm{PM})$ and $75 \%$ rec. $\mathrm{N}+\mathrm{BGA} 10 \mathrm{~kg} \mathrm{ha}^{-1}$ which yielded significantly less during both the years. 
Table.1 Energetics of safflower production as influenced by integrated nitrogen nourishment

\begin{tabular}{|c|c|c|c|c|c|c|c|c|c|c|c|c|}
\hline \multirow[t]{2}{*}{ Integrated N nourishment } & \multicolumn{2}{|c|}{$\begin{array}{l}\text { Seed yield } \\
\text { q ha }\end{array}$} & \multicolumn{2}{|c|}{$\begin{array}{l}\text { Total energy output } \\
\text { MJ x } 10^{3}\end{array}$} & \multicolumn{2}{|c|}{$\begin{array}{l}\begin{array}{l}\text { Energy } \\
\text { efficiency } \\
\text { (biomass) }\end{array} \\
\mathrm{Kg} \mathrm{M}_{\mathbf{M}} \mathbf{M J}^{-1}\end{array}$} & \multicolumn{2}{|c|}{$\begin{array}{l}\text { Energy intensiveness } \\
\text { MJ Rs }^{-1}\end{array}$} & \multicolumn{2}{|c|}{$\begin{array}{l}\text { Energy productivity } \\
\text { g MJ ha-1 }\end{array}$} & \multicolumn{2}{|c|}{$\begin{array}{l}\text { Energy output } \\
\text { input ratio }\end{array}$} \\
\hline & $\begin{array}{l}\text { 2001- } \\
02\end{array}$ & $\begin{array}{l}2002- \\
03\end{array}$ & $\begin{array}{l}2001 \\
-02\end{array}$ & $\begin{array}{l}2002 \\
-03\end{array}$ & $\begin{array}{l}\text { 2001- } \\
02\end{array}$ & $\begin{array}{l}2002- \\
03\end{array}$ & $\begin{array}{l}\text { 2001- } \\
02\end{array}$ & $\begin{array}{l}2002- \\
03\end{array}$ & $\begin{array}{l}\text { 2001- } \\
02\end{array}$ & $\begin{array}{l}2002- \\
03\end{array}$ & $\begin{array}{l}\text { 2001- } \\
02\end{array}$ & $\begin{array}{l}2002- \\
03\end{array}$ \\
\hline \multicolumn{13}{|l|}{ Residual } \\
\hline $\mathbf{N}_{0}$ - No nitrogen & 12.80 & 13.41 & 70.92 & 74.22 & 1.12 & 1.17 & 11.27 & 11.79 & 324.39 & 339.07 & 18.04 & 18.84 \\
\hline $\mathrm{N}_{1}-100 \%$ rec. $\mathrm{N}$ & 14.40 & 15.20 & 78.05 & 82.28 & 1.24 & 1.31 & 12.42 & 13.10 & 369.24 & 390.18 & 20.10 & 21.22 \\
\hline $\mathbf{N}_{2-} 75 \%$ rec. $N$ & 13.68 & 14.31 & 75.41 & 78.81 & 1.19 & 1.25 & 11.99 & 12.54 & 346.86 & 366.53 & 19.17 & 20.25 \\
\hline $\mathrm{N}_{3^{-}} 75 \%$ rec. $\mathrm{N}+25 \% \mathrm{~N}(\mathrm{FYM})$ & 16.43 & 17.30 & 86.66 & 91.18 & 1.44 & 1.51 & 13.84 & 14.56 & 444.81 & 466.78 & 23.52 & 24.66 \\
\hline $\mathrm{N}_{4^{-}} 75 \%$ rec. $\mathrm{N}+25 \% \mathrm{~N}(\mathrm{PM})$ & 15.88 & 16.54 & 83.93 & 87.37 & 1.40 & 1.46 & 13.41 & 13.97 & 430.46 & 451.66 & 22.82 & 23.92 \\
\hline $\mathrm{N}_{5}-75 \%$ rec. $\mathrm{N}+25 \% \mathrm{~N}(\mathrm{WS})$ & 16.15 & 17.15 & 85.25 & 90.47 & 1.41 & 1.51 & 13.62 & 14.47 & 437.34 & 467.30 & 23.15 & 24.71 \\
\hline $\mathrm{N}_{6^{-}} \mathbf{7 5} \%$ rec. $\mathrm{N}$ blended with $\mathrm{CDU}$ & 17.31 & 18.41 & 89.32 & 94.90 & 1.47 & 1.57 & 14.27 & 15.17 & 467.56 & 500.47 & 24.23 & 25.92 \\
\hline $\mathrm{N}_{7^{-}} \mathbf{7 5} \%$ rec. $\mathrm{N}$ blended with cowdung & 17.15 & 18.04 & 88.58 & 93.17 & 1.46 & 1.54 & 14.15 & 14.89 & 463.02 & 490.00 & 24.02 & 25.40 \\
\hline $\mathrm{N}_{8^{-}} 75 \%$ rec. $\mathrm{N}+$ BGA $10 \mathrm{~kg} \mathrm{ha}^{-1}$ & 14.05 & 15.03 & 76.98 & 82.14 & 1.22 & 1.31 & 12.25 & 13.08 & 360.06 & 386.75 & 19.76 & 21.22 \\
\hline $\mathbf{S E m} \pm$ & 0.46 & 0.51 & 2.31 & 2.40 & 0.04 & 0.05 & 0.45 & 0.49 & 9.56 & 9.79 & 0.73 & 0.79 \\
\hline $\mathrm{CD}(\mathrm{p}=0.05)$ & 1.38 & 1.52 & 6.92 & 7.17 & 0.13 & 0.16 & 1.35 & 1.46 & 28.63 & 29.27 & 2.17 & 2.35 \\
\hline \multicolumn{13}{|l|}{ Direct } \\
\hline$T_{1}$ - No nitrogen & 11.91 & 12.85 & 64.23 & 69.22 & 1.79 & 1.92 & 10.81 & 11.65 & 538.86 & 581.30 & 29.06 & 31.32 \\
\hline $\mathbf{T}_{2}-50 \%$ rec. $\mathbf{N}+$ Azotobacter & 14.70 & 15.52 & 79.10 & 83.49 & 1.20 & 1.27 & 12.66 & 13.36 & 362.88 & 383.18 & 19.53 & 20.61 \\
\hline $\begin{array}{l}\mathbf{T}_{3^{-}} \mathbf{5 0} \% \text { rec. } \mathbf{N}+\text { Azotobacter }+ \\
\text { Azospirilum }\end{array}$ & 16.94 & 17.72 & 89.93 & 94.01 & 1.35 & 1.41 & 14.37 & 15.02 & 416.11 & 435.46 & 22.09 & 23.10 \\
\hline $\mathrm{T}_{4^{-}} \mathbf{1 0 0} \%$ rec. $\mathrm{N}$ & 17.73 & 18.53 & 93.45 & 97.52 & 0.97 & 1.01 & 14.27 & 14.89 & 301.59 & 315.06 & 15.89 & 16.59 \\
\hline $\mathrm{SEm} \pm$ & 0.29 & 0.60 & 0.34 & 0.43 & 0.02 & 0.02 & 0.09 & 0.11 & 1.52 & 1.72 & 0.13 & 0.16 \\
\hline $\mathrm{CD}(\mathrm{p}=0.05)$ & 0.82 & 1.74 & 0.98 & 1.22 & 0.05 & 0.05 & 0.27 & 0.33 & 4.35 & 4.93 & 0.36 & 0.45 \\
\hline
\end{tabular}


Residual effect of control, being poor most produced at par seed yield with $75 \%$ rec. $\mathrm{N}+$ BGA $10 \mathrm{~kg} \mathrm{ha}^{-1}$ and $75 \%$ rec. $\mathrm{N}$ in first year. Whereas, in second year, it was at par to only $75 \%$ rec. N. Direct application of integrated nitrogen nourishment to safflower resulted in the highest seed yield under $100 \%$ rec. N, though, it was statistically similar to $50 \%$ rec. $\mathrm{N}+$ Azotobacter + Azospirilum during both the years.

Energy parameters of safflower production revealed significant difference in total energy output, energy use efficiency, energy intensiveness, energy productivity and energy output-input ratio in response to residual and direct influence of integrated nitrogen nourishment (Table 1).

The total energy output was maximum under the residual of $75 \%$ rec. $\mathrm{N}$ blended with CDU and it was statistically similar to $75 \%$ rec. $\mathrm{N}$ blended with cow dung, $75 \%$ rec. $\mathrm{N}+25 \%$ $\mathrm{N}(\mathrm{FYM}), 75 \%$ rec. $\mathrm{N}+25 \% \mathrm{~N}(\mathrm{WS})$ and 75 $\%$ rec. $\mathrm{N}+25 \% \mathrm{~N}(\mathrm{PM})$ during both the years. The trend of energy intensiveness, energy use efficiency and energy output-input ratio was similar to total energy output. Energy productivity was also found highest under the $75 \%$ rec. $\mathrm{N}$ blended with CDU which was significantly superior over rest of the treatments, except $75 \%$ rec. $\mathrm{N}$ blended with cow dung and $75 \%$ rec. $\mathrm{N}+25 \% \mathrm{~N}$ (FYM) during first year but in second year it was only at par to $75 \%$ rec. $\mathrm{N}$ blended with cow dung. This was due to higher productivity of grain yield and less energy input. Similar results were also reported by Pal et al (1995) and Parihar et al (1999). Among direct applied treatments, $100 \%$ rec. $\mathrm{N}$ obtained the maximum total energy output which was significantly differ to other treatments during both the years. With regard to energy use efficiency, energy productivity and energy output-input ratio, no nitrogen was significantly differ to all other treatments. But energy intensiveness was found maximum under the application of $50 \%$ rec. $\mathrm{N}+$ Azotobacter + Azospirillum and was significantly superior over rest of the treatments except $100 \%$ rec. N. Total energy output was maximum with $100 \%$ rec. $\mathrm{N}$ due to higher grain and straw yield.

\section{References}

Burnett, M. 1982. Energy analysis of three agro systems. (In) Basic Techniques in Ecological farming, $I n$ : $2^{\text {nd }}$ International Conference, IFOAM, Montreal, October 1-5, 1978. Pp 183-195.

Mittal, J.P. and Dhawan, K.C. 1988. Research manual on energy requirements in agricultural sector. $\mathrm{Pp}$ 20-23.

Oelke, E.A., Oplinger, E.S., Teynor, T.M., Putnam, D.H., Doll, K.D., Kelling, K.A., Durgan, B.R. and Noetzel, D.M. 1992. Safflower. Alternative Field Crops Manual.

Pal, M., Singh, K.A., Saxena, J,P. and Singh, H.K. 1985. Energetics of cropping systems- A review. Indian J. Agron. 30: $1-61$.

Paneswar, B.S. and Bhatnagar, A.P. 1994. Energy norms for inputs and outputs of agricultural sector. Pages 5-16 in S.K. Verma, J.P. Mittal and S.Singh, editors Energy management and conservation in agricultural production and food processing. USG Publ. and Distr., Ludhiana, India.

Parihar, S.S., Pandey, D., Shukla, R.K., verma, V.K., Chaure, N.K., Chaudhary, K.K. and Pandya, K.S. 1999. Energetics, yield, water use and economics of rice- based cropping system. Indian J. Agron. 44: 205-209.

Reddy,Ch. P., Lakshmi, G.S. and Santharan, M.V. 1994. Effect of levels of nitrogen and azospirillum inoculation on oil, protein content and oil yield of safflower and on $\mathrm{N}, \mathrm{P}, \mathrm{K}$ uptake. J. 
Oilseeds Res. 11 (1): 34-39.

Wani, S.P., McGill, W.B., Haugen Kozyra, K.L., Robertson, J.A. and Thruston, J.J. 1994. Improved soil quality and barley yield with fababeans, manures, storage and crop rotation on a grey luvisal. Canadian J. Soil Sci. 74 : 75-84.

\section{How to cite this article:}

Mishra, P. K. 2020. Influence of Integrated Nitrogen Nourishment on Seed yield and Energetics of Safflower in Hybrid rice- Safflower Cropping System. Int.J.Curr.Microbiol.App.Sci. 9(01): 2333-2337. doi: https://doi.org/10.20546/ijcmas.2020.901.265 